\title{
Research on the Practical Teaching Reform of Information Management and Information System
}

\author{
$\mathrm{Xu}$ Jingxiu \\ Huanggang Normal University \\ Huanggang, China \\ e-mail:xujingxiu123@126.com
}

$\mathrm{Xu}$ Yuanpeng

Huanggang Normal University

Huanggang, China

e-mail: 31374209@qq.com

\begin{abstract}
In Huanggang City ,informatization construction is strengthened step by step nowadays, whether in state-owned enterprises, institutions such as the administrative department for Industry and commerce at various levels, various private enterprises, financial, securities, or the public service industries such as hotels, large supermarkets, colleges, schools and other, all are strengthening the construction of information, that is information management and information systems analysis, design, maintenance and security precaution ability. Practice teaching reform is discussed on training model of info management and system. At the very beginning, study the following problems: the traditional personnel training mode of information management and information system is out of touch with the needs of society, the practice teaching system is not reasonable and the practical ability training goal is not clear, the training mode is single, etc. Put forward the practice teaching reform that enhance the link of modular practice teaching, pour a strong foundation for experimental courses, promote the link of modular training, comprehensively improve the link of project training and the production practice, establish a good practice evaluation and build a excellent teaching team, etc.
\end{abstract}

Keywords-infomation;management;Training;Practice;refo $r m$

Foundation item: Huanggang Normal University research project (2014CE28)

The specialty of information management and information system integrates of five specialties : economic information management, information technology, information science, forestry information and the management information system[1], is a strong cross-discipline practice, it is produced in the Integration of multiple disciplines, but the actual teaching has not been truly digested together, students' classroom learning is only a simple combination of many kinds of specialty knowledge, students cannot effectively to apply the learning into practice, thus the graduates' ability of social practice is far from the requirements of the specialty

\author{
Li Bifeng \\ Huanggang Normal University \\ Huanggang, China \\ e-mail:93235119@qq.com
}

training objectives, the graduates is inadequate to the competitive job market.

The specialty of information management and information system is based on computer technology and management, the highly integration of computer technology and management science is fully embodied the characteristics of " informationization to promote industrialization "[2], therefore the specialty has been generally set up and become a key construction specialty in the domestic and foreign universities. Because the specialty personnel training mode is to develop a highly integrated strategic information management and information system development talents, the graduates must fit actual enterprise operation ability requirements of personnel information management and information system, so what kind of practice training mode the specialty of information management and information system should be established, in order to meet the demand of social needs while at the same time the graduates enhance competitive advantage, become our urgent study.

\section{PRESENT STATUS OF INFORMATION MANAGEMENT AND INFORMATION SYSTEM}

\section{A. the traditional mode of major talent training out of}

touch with the needs of society

In 427 undergraduate colleges and universities in our country which set up the specialty of information management and information system, because of different major disciplines background, different departments which is relied on, different nature, cause different training direction and Training objectives. Generally college major talent training mode has three kinds: one is to emphasize the skill of IT technology, weakening of modern management theory and method, but cannot compete with graduates of the computer science and technology; two is to emphasis the management and too weakened IT technology, cause the students could not use advanced IT 
technology to enhance the level of enterprise management; three is both equally technology and management, course no key points or key points too much, the students do not know how to learn, the effect is not ideal. This brings a different degree of hidden trouble to the major talent training and employment etc...

\section{B. the practice teaching system is not reasonable}

In the aspect of teaching practice, many schools stress on theory and pay little attention on practice. They lack of perfect practical teaching system in the training of professional practice ability, short of practice teaching resources. Namelylack ofthe practical teaching system of inducting and training students'comprehensive, innovative personnelability, a great many specialty teachers compilepractical teachingoutlines by their ownideas, oftenteaching is only basic skill trainings, so a lot of practical contents repeated,but the knowledge and the new skill is not embodied.

training equipment. lack of experience, and then influence the students' practical ability training[3].

\section{C. practice ability training goal is not clear, Training \\ mode is single}

At present, the overall goal of China's higher education gradually from elite education to popular, social and long-term change. Especially in the local colleges and universities in Huanggang, the education structure and level and its cultivation target of information management and information system speciality is adjusted and divided, in order to adapt to these changes. From the training objectives of the original undergraduate professional elite talent, professional personnel, to the development of wide caliber, fundamental direction. Broaden the breadth of knowledge and ability, make the students' knowledge structure and comprehensive ability in information management and information system has stronger adaptability to society, especially the ability of self-study. The training goal of information management and information system specialty in our institute can transform to occupation application, that is not academic or research, according to the needs of higher education layout of Hubei province and regional economic development, especially the need of Huanggang City, combining with the characteristics of our teachers and students, in fact, training major undergraduates to academic talents, neither necessary nor possible. Our college graduates will have a considerable part to take graduate classes, or directly go abroad to study, but most of the students will directly get a job. Undoubtedly, purpose of cultivation of undergraduate should have very different with the junior college student, but should not make the scientific research and academic talents as a blueprint, yet should be composite application-oriented talents of "broad extension and deep foundation, strong ability, high quality".

Therefore, specific training objectives of information management and information system speciality is: fostering applied technological talents in enterprises or government departments of information technology, economic sectors or management department, engaging in the information system analysis, design, development, use and maintenance, or engaging in the management of information technology, the development work of information system project and the information resources. It differs from Not only the computer software specialty, but also with other management majors. These people can engage in the occupation: information systems analysts, information systems designers, network system maintenance technicians, programmers, database administrators(DBA), technician information department supervisors, IT project development group managers, information system administrators, e-commerce technicians and administrators and other work of information industry.

In our college, not only the practice ability training objectives of the speciality of information management and Information System is not clear, but also the way of trainging is single. In the traditional teaching process of information management and information system specialty students, while the theory teaching, have not strengthen practice teaching, rarely used project teaching, module teaching, simulation teaching, the actual project participation practices and other culture forms, as well as the supporting measures, to build a set of complete and various training methods.

\section{THE CONTENT OF PERSONNEL TRAINING MODE AND PRACTICE TEACHING REFORM}

The specialty of information management and information system is a modern relatively and interdisciplinary new discipline of economics, management science, computer science and technology and other discipline. So in order to adapt to the training mode of applied technological undergraduate talents, We need combine with Hubei Province, Huanggang city and our college's status, to draw up a personnel training project, and on this basis, carry on the course system construction, teachers team construction and teaching reform practice. By investigation, understand the society, industry demand, reference point school professional construction experience, combined with local characteristic to formulate the personnel training program of applied technological undergraduate talents and Specific training objectives of information management and information system; formulate a practical skills training module, carry on practice teaching and training projects through these modules, simulate practice base of enterprise information management mode, so that students in analog environment carry on the design and practice. The practice training courses system as shown in Fig .1, practice teaching reform follows the following links. 


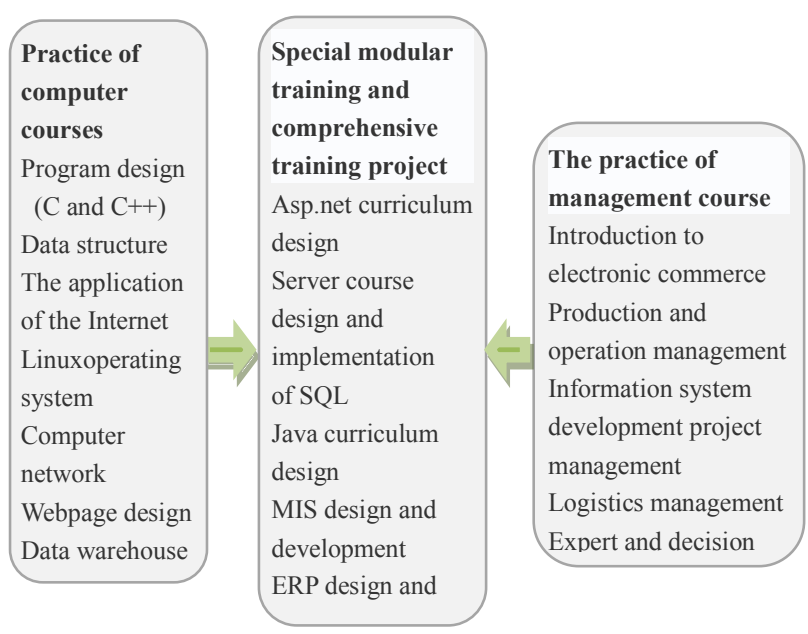

Figure 1. The practical curriculum system arrangement

\section{A. Enhance the modular practice teaching}

The Specialty of Information management and Information System is different by cultivating goal and career positioning in different types Universities, different colleges. Our school it is opened by the college of computer, will focus on the enterprise information management module and the development of enterprise information system module to make the practice teaching plan, the plan should fully embody the characteristics of major interdisciplinary[4], truly achieve mastery of knowledge between information and management, management system, training requirements, focusing on the design of ERP system's development, implementation and application ability, make the students to apply professional knowledge effectively integrated into practice, in order to facilitate the innovation talents training.

\section{B. Pour a strong foundation of experiment teaching}

Experiment teaching is an important platform of the combination of theory with practice, improving the students' practical ability, and mastering the theory through practice. According to the characteristics of the specialty of information management and information system in our college, the course experiment teaching should be based on the theory of cultivating system, combining with social demand on the ability of students, to construct a theory of culture system with a combination of experimental training system[5]. The students will verify, simulation and design of classroom theoretical knowledge learned, mainly use the situational teaching environment.

Pour a strong foundation of experiment teaching, first need to create a good experimental platform, thus set up a school laboratory to configure hardware and software reasonably, and can design the management and development of information management system for the enterprise research, establish the corresponding simulation experimental base, or cooperating with the Huanggang region enterprises to establish cooperation Laboratory, make full use of the resources of the enterprise, train the students' practical ability[6].

\section{To promote special modular training}

According to the goal of talent training, the special modular training of information management and information system of our college mainly need open: enterprise information management module and enterprise information system development module.

The training objectives of enterprise information management module are: to master basic theories of information management and information system, can be engaged in the information resources management, information consultation and enterprise informatization process et, comprehensive, specialized personnel with good occupation could deal with the problems by modern information technology skilled, have management ability and innovation ability. With the goal orientation, under the guidance of the teacher, students can carry on information management in the information management simulation base in targeted: such as the ERP system implementation, ERP system application, human resources management, marketing and planning[7]

The training objectives of the enterprise information system development module are: to master basic theories of information management and information system, master the design method of information system, familiar with the programming language, understand the development of the dynamic frontier disciplines and related fields, with the information system analysis and design, implementation and software development capabilities. With the goal orientation, under the guidance of the teacher, students can carry on information management in the enterprise information system development module base in targeted, such as: ERP system software development, HR system software development, web site development and promotion and other marketing.

In the special modular training process, students are grouped and designated special training content, the college should allocate a centralized time and practice base, let the students systematically, completely carry on the special training. Teacher should counsel in the whole practical training, student can communicate with the teacher if have doubts, teachers should conduct acceptance and evaluation after practical training[8].

\section{The improvement of comprehensive project training}

\section{And the production practice link.}

Teacher mainly lead the students to do the provincial or university level college students innovation project in this link, combined with the specific project practice, focusing on the research ability and innovation ability of college students'. Regularly these projects have funds to support, teachers as guidance counselor, the project is composed of 5 peopleusually, a relatively highly capable student as leader, complete during undergraduate study by the guidance of teachers. Through participation in the project, write the related papers, and in practice to exercise their own, so that students can quickly adapt to the future occupation role[9].

Production practice of enterprises is the teaching process that students contact the society, put the theory into practice, students of information management and information system must actively participate in. Colleges 
generally arrange fourth year university students to enable the concrete operation in the information management, information system development and application and other related post practice for a period of time, understand the specific work process and the different mode in the practical work of the enterprises of information management and information system development and application, so that students' professional knowledge and practice be well combined. The vice president in charge of teaching, office directors of information management and information system, counselors, homeroom teachers, etc. comprise the practice leading group, responsible for the overall layout arrangement, implement various internship matters. Internship instructor is responsible for the internship process guidance to students, regular goes to enterprises to know the student's practice and thoughts, actively cooperate with the practice unit and do a good job in the management of interns. The evaluation of enterprise production practice shall be borne by the opinions of practice unit, students' internship report, survey report, guidance teachers' evaluation and finally make comprehensive evaluation.

\section{E. The establishment of good practice evaluation}

The practice evaluation of the course of information management and information system is critical, examination mode settings are properly directly affect the students' practical learning interest and enthusiasm, must carry on the reform and innovation, online examination system is the best form for testing information management project. Let the students randomly selected computer problem, write project program and project management test items. For unqualified students of the practical course exam, they need to retake the practice teaching course. Through this innovation evaluation, stop students' plagiarism of practice examination, perfunctorily practice teaching from a large extent.

\section{F. Building a good teaching team}

From our school professional training plan at present, almost all of the practice teaching is authentication type, professional teachers themselves lack of practical work background and practice experience, it is difficult to guide the students to complete the design or the innovative experiment. Therefore, the school should make various efforts, create good teaching team. Hiring from outside, on the one hand, to attract the excellent professional master, doctor graduate students to work in our college, to expand the full-time teachers, to form professional teaching teams at all levels. In the formation of all levels of teaching team, should to avoid the teacher's knowledge structure and professional assimilative, absorb some professional talents of different specialty or discipline background into the teachers as far as possible. On the other hand, try to absorb some related experts engaged in the actual practice of education or employing as part-time teachers, let them participate in the actual classroom teaching in school. to create the "double teacher type" of teachers, we should advocate life-long learning, constantly update their knowledge structure[10], improve the hands-on and practical ability. To update their own knowledge structure by new information technology, improve the teaching level and practice ability.

Our full-time teachers mostly get the job from school graduation, theoretical knowledge are very solid, suitable for classroom teaching, but lack of social experience, not much specific practice experience, if to solve practical problems in the work, they will be faced with great difficulty. And part-time teacher's unique background and experience knowledge can just make up for this deficiency, broaden the students' learning vision, enrich students' learning experience, make the students learn some real practical experience and skills. Mutual collocation of full-time teachers and part-time teachers, formed a perfect and efficient professional teaching team, to be able to develop senior professionals that truly meet the needs of the society with comprehensive ability .

\section{CONCLUDING REMARKS}

At present, the society has already entered the information science and technology fast developing era, the information talents have more and more demands in the field of economic management, electronic commerce, financial engineering and etc.. At the same time, the state also proposed " informationization to promote industrialization ", this causes Colleges and universities to cultivate qualified information management and information systems talents, and also signals the teaching reform of information management and information system is imperative.

\section{REFERENCE.}

[1]China Management Informationization: The course setting and discuss of information technology of information management and information system:Article in a journal:

[2]Higher education of sciences: Design and Practice of Innovative Practical Teaching System Majoring in Information Management and Information System :Article in a journal:

[3]China Management Informationization: Practical Teaching System Research of information management and Information System -research results based on CISC2010:Article in a journal:

[4]Shi Hongxia. Exploration of students' practice and innovation abilities of information management and Information System, education exploration,2007,pp,10

[5]Computer Study: Research on Teaching Reform on IMIS Practice Article in a journal:

[6]Zhang ShiYu. Introductory tutorial for information management and information system,Tsinghua University press,vol.I,pp.80-100, November 2009.(references)

[7]Liu ChuLu. Tutorial for Project Management Professional of information management,Tsinghua University press, vol.II,pp. 450-460,March 2013. (references)

[8]China Management Informationization: The practice curriculum system design based on the cultivation of comprehensive ability of information system application 2010:Article in a journal:

[9]Yi RongHua. Tutorial for management information system, Higher Education Press, vol.I,pp.88-102,April 2012. (references)

[10]Journal of Modern information: Study on Practice Reform and Innovation of Information Managem ent and Information System 2009:Article in a journal: 